\title{
Current alternatives in the prevention and treatment of xerostomia in cancer therapy
}

\section{Alternativas atuais na prevenção e tratamento da xerostomia decorrente dos tratamentos antineoplásicos}

\author{
Tainara BARBIERI ${ }^{1}$ iD 0000-0001-7079-916X \\ Kiany Claudia da COSTA ${ }^{1}$ iD 0000-0002-8623-8575 \\ Letícia de Freitas Cuba GUERRA' ${ }^{1}$ iD 0000-0001-9439-436X
}

\begin{abstract}
In the last decades, there has been a substantial increase in the occurrence of cancer. The most commonly used treatment for this disease involves surgery, radiotherapy and chemotherapy. These treatment modalities are associated with different kinds of side effects, acute or late. Xerostomia is one of the main oral complications that affect patients undergoing antineoplastic treatments, mainly head and neck cancer patients. It is characterized by a "dry mouth" sensation resulting from decreased salivary flow. It is persistent and affects the integrity of oral tissues, thereby significantly affecting patients' quality of life. Many strategies have been applied and others developed to prevent and reduce xerostomia. Accordingly, the objective of this study was to review the literature about current prevention and treatment measures aimed at improving the quality of life of xerostomic patients.
\end{abstract}

Indexing terms: Drug therapy. Disease prevention. Radiotherapy. Therapeutics. Xerostomia.

\section{RESUMO}

O câncer vem apresentando um aumento significativo na sua incidência nas últimas décadas. Os tratamentos mais utilizados para tratar essas doenças continuam sendo o tratamento cirúrgico, a radioterapia e a quimioterapia. O emprego dessas formas de tratamento está associado a diferentes tipos de efeitos colaterais agudos ou tardios. A xerostomia é uma das principais manifestações bucais que acometem os pacientes submetidos ao tratamento antineoplásico, afetando principalmente pacientes com câncer de cabeça e pescoço. Caracteriza-se pela sensação de "boca seca" decorrente da redução da produção de saliva. Ela é persistente e afeta a integridade dos tecidos epiteliais bucais, consequentemente, afetando significativamente na qualidade de vida dos pacientes oncológico. Numerosas estratégias estão sendo aplicadas e outras desenvolvidas para a redução e prevenção da xerostomia. Desta forma, o objetivo deste trabalho foi revisar a literatura sobre práticas atuais de prevenção e tratamento, que visem à melhora do quadro de saúde dos pacientes xerostômico.

Termos de indexação: Tratamento farmacológico. Prevenção de doenças. Radioterapia. Terapêutica. Xerostomia.

\section{INTRODUCTION}

Cancer refers to a set of more than 100 diseases characterized by the disordered growth of cells, whichcan invade tissues and organs. Dividing rapidly, these cells tend to be very aggressive and uncontrollable, determining the development of malignant neoplasms. According to the World Health Organization (WHO), cancer accounts for

$\boldsymbol{\nabla} \mathbf{v} \boldsymbol{\nabla}$

1 Universidade Paranaense - UNIPAR, Curso de Odontologia, Departamento de Estomatologia. Av. Júlio Assis Cavalheiro, 2000, Centro, 85601-000, Francisco Beltrão, PR, Brasil. Correspondence to: T BARBIERI. E-mail: <thay_barbieri@hotmail.com>.

$\boldsymbol{\nabla} \mathbf{v} \boldsymbol{\nabla}$

How to cite this article

Barbieri T, Costa KC, Guerra LFC. Current alternatives in the prevention and treatment of xerostomia in cancer therapy. RGO, Rev Gaúch Odontol. 2020;68:e20200016. http://dx.doi.org/10.1590/1981-86372020000163546 
about one in five deaths worldwide. More than 14 million people develop some type of cancer every year, and the projection is that this number will grow to more than 21 million in 2030. According to the estimates of the National Cancer Institute(INCA), the most frequent types in Brazil will be: in men - prostate $(28.6 \%)$, lung $(8.1 \%)$, intestine $(7.8 \%)$, stomach $(6.0 \%)$ and oral cavity $(5.2 \%)$; in women - breast $(28.1 \%)$, intestine $(8.6 \%)$, cervix $(7.9 \%)$, lung $(5.3 \%)$ and stomach (3.7\%) [1].

The strategies for the treatment of malignant neoplasms are complex, and of different types. They can be performed individually or in combination, and surgery, chemotherapy (CT) and radiotherapy (RT) are the most used antineoplastic therapies [2].

$\mathrm{CT}$ consists in the use of drugs that killrapidly growing cells, such as in malignant tumors, by inhibiting synthesis or DNAor blocking its essential functions or inducing apoptosis. Because it is a systemic treatment, healthy tissues can be affected, albeit to varying degrees [2].

$\mathrm{RT}$ is a therapeutic modality, main or adjunct, widely used in the treatment of malignant neoplasms. Its aim is to administer a dose of irradiation at a defined volume, with the lowest possible damage to adjacent normal tissues, resulting in tumor eradication, better quality of life $(\mathrm{Q} o \mathrm{~L})$, and increased survival rates [3].

Such treatments are not selective for malignant cells, and consequently, they cause damage to normal tissues, affecting the QoL of patients. Adverse effects may be acute, manifesting during treatment, or late, appearing months or years after the end of treatment [4].

One of the most common side effects of CT and $\mathrm{RT}$ is xerostomia, defined as the subjective sensation of dry mouth. It is a consequence of reduced production of saliva, called hyposalivation. Xerostomia is responsible for the sensation of "dry mouth" and burning mouth, frequent complaints of patients submitted to these treatments [5]. Reduced salivary flow can impair basic oral functions and increase the risk of caries, periodontal disease and opportunistic infections, directly influencing patients' QoL [6].

Although it is a common and extremely unpleasant change, xerostomia control as well as salivary hypoflow mainly consists of palliative treatments, including the application of saliva substitutes and stimulants, low-power laser therapy and prescription drugs [7].
In view of the difficulty of managing xerostomia and its negative impact on patients' QoL, the objective of the present study was to carry out a survey of the current literature, searching for new and potential alternatives for the treatment and prevention of xerostomia associated with cancertreatment.

\section{Xerostomia induced by cancer treatment}

Xerostomia is defined as "dry mouth" sensation. It presents symptoms related to the lack of saliva caused by a decrease, interruption of loss of quality of salivary gland function [8].

In addition to playing a vital role in the protection of the oral mucosa, saliva is associated with antimicrobial action and protection of the dental structures, and it aids in the digestive, gustatory and speech processes [9].

Inadequate salivary function causes discomfort to patients, making them more susceptible to multiple problems, including poor dental hygiene, propensity for oral infections, periodontal disease, rampant caries, sleep disorders, oral pain and difficulty in chewing and swallowing [10].

Its etiology and modifying factors vary extensively and are strongly related to cancer treatment that causes damage to salivary gland tissues. However, they may be associated with other conditions, such as medications and diseases [7].

\section{Xerostomia associated with radiotherapy}

RT in patients with head and neck cancer presents a series of complications due to the undesirable effects of radiation, which since it is a non-selective treatment, affects neoplastic cells and healthy cells $[3,11,12]$.

Radiation-induced oral complications are complex and dynamic pathobiological processes. There is considerable evidence that the cytotoxic effects of ionizing radiation are due to the physico-chemical reactions that lead to the production of free radicals (FR). These compounds would also act as mediators in lesions to salivary gland [13].

Once RT is administered, the radiation exerts direct effects on DNA, inducing strand breaks. At the same time, there is release of $R L$ and a consequent imbalance in oxidative stress reactions, which plays a crucial role in the initiation of cell damage in the salivary glands [13]. 
The development of xerostomia also depends on multiple factors such as the dose and frequency of RT, irradiated volume and site, age, systemic conditions of the patient and associated treatments [4].

Studies have shown that glandular tissues are highly sensitive to radiation. Doses of 20 Gray (Gy) can cause reduction of salivary flow, while doses over 50Gy are able to generate irreversible cessation, leading to worsening compromised conditions of oral tissues, generally in the first trimester after the beginning of RT [5]. Considering that the treatment of oral carcinomas usually requires adose of 60 to 70 Gy, RT may lead to a rapid decline in salivary flow during the first week of radiation, with eventual reduction of $95 \%$ in the region. After five weeks of irradiation, both stimulated and resting flow are inhibited, virtually ceasing, and rarely fully recover [13].

\section{Xerostomia associated with chemotherapy}

CT is acancer treatment modality that has a higher rate of cure and increased survival14. It is based on the administration of drugs that mostlyact on the mitotic phase of tumor cells due to cytotoxic action and induction of cell death [14].

These cytotoxic actions are systemic, occurring in tumor cells and normal cells, causing damage mainly to the tissues of the oral mucosa $[6,15]$. This isdue to the constant process of cell renewal in the oral mucosa, making it more vulnerable to the effects of antineoplastic drugs, where many of these cause kill actively growing cells because they affect the synthesis DNA, RNA or proteins [15].

Antineoplastic drugs may have a direct effect on the oral mucosa by the secretion of chemotherapeutic substances in saliva, or indirectly by the suppression of the production of immune cells in the bone marrow [14]. Drug toxicity appears to be directly linked to reduced cell turnover in the basal layer of the epithelium, resulting in desquamation, ulceration, inflammation and atrophy $[14,16]$. Exposure of the oral mucosa to drugs seems to contribute to the development of pathologies such as mucositis, xerostomia and gingival bleeding 16 . In a study conducted by Freire et al. [13], the drugs gemcitabine, doxorubicin, fluoruracil and cyclophosphamide showed greater cytotoxicity in the oral cavity.

Xerostomia is one of the most common manifestations associated with some medications, including drugs used for antineoplastic chemotherapy such as paclitaxel, carboplatin, cisplatin and 5-fluorouracil $[14,17]$.

Xerostomia occurs to some extentdue to the concentration of chemotherapeutic agents in saliva, which results in exposure of the oral mucosa to toxicity $[16,17]$.

In a recent study, in which 127 patients with advanced cancer were evaluated, xerostomia was the fourth most reported symptom (78\% of patients). The degree of xerostomia was related to the total number of chemotherapeutic drugs used. Xerostomia was identified as the third most disturbing symptom, and its severity was related to mouth discomfort, dysgeusia, dysphagia and dysphonia [13].

The literature suggests that chemotherapeutics can quantitatively and qualitatively alter salivary flow and saliva components, such as salivary amylase and immunoglobulin A $(\lg A)$. This can lead to an increase in salivary viscosity and decrease in flow, consequently causing the sensation of dry mouth, which causes discomfort in eating and speaking and predisposition to oral candidosis, traumatic lesions, dysphagia and increase in caries $[14,16]$.

\section{Diagnosis}

To diagnose xerostomia, the patient must undergo a careful clinical evaluation, which consists in the inspection of the oral mucosa, state of hydration, presenced of saliva under the tongue and its macroscopic appearance, and presence of soft tissue lesions and caries, among others [8].

Salivary flow rates provide essential information about the function of the salivary glands. To evaluate the secretion and involvement of these glands, several methods have been developed, for example, self-reported questionnaires, simple functional measures such as observing whether a dental mirror adheres to the oral mucosa or if a patient can chew and swallow dry biscuits without water, andsialometry and scintigraphytests as well $[8,18]$.

Sialometry is the most objective test to evaluate the function and volume of saliva [18]. It is a method that measures the amount of saliva produced in a given time interval [8]. One of the most widely used sialometry techniques is the weighing of two cotton balls, after their placement for a fixed time on the mouth floor. The ratio of the starting weight to the final weight of the rollers is converted into milliliters per minute $(\mathrm{ml} / \mathrm{min})$. Another 
widely used methodis based on the stimulation of saliva by chewing on a piece of paraffin. Stimulated saliva and resting saliva can be collected in a Falcon test tube and then compared according to a universal table [19].

Scintigraphy is an examination that consists of placing the patient in a scintillation chamber, injecting an intravenous drug as a marker and taking images for $30 \mathrm{~min}$. After $15 \mathrm{~min}$, oral stimulation is performed; the injected drug is first concentrated and then eliminated by the salivary glands, and the function and excretion of the marker by the glands is thereby evaluated [8]. In spite of its efficiency, the added cost for this examination makes it rarely indicated in clinical routine.

In the precise diagnosis of xerostomia, morphological and functional assessments are also proposed, such as histological examination, computed tomography, magnetic resonance imaging (MRI) and ultrasound. As these methods are technically complex and not part of the reality in the overall clinical scenario, these assessments are mainly based on self-reports from patients, especially considering that xerostomia is a subjective symptom [20].

The early diagnosis of xerostomia allows the establishment of management strategies that favor the reduction of sequelae, providing more comfort and QoL for patients. Dentists play an essential role in diagnosing and treating patients with xerostomia [21].

\section{Clinical manifestations and complications associated with xerostomia}

Saliva plays a key role in maintaining oral cavity balance [3]. Salivary pH varies between 6.5 and 7.4, staying at adequate levels due to its buffering capacity [22]. Saliva has several functions, such as tissue repair, mouth lubrication, $\mathrm{pH}$ maintenance and neutralization of acidity, formation of the foodbolus, antimicrobial, antiviral and antifungal action, and maturation of dental enamel and protection against demineralization.

The first and most common symptom reported by patients affected by xerostomia is the discomfort caused by dry mouth sensation due to reduced salivary flow caused by inadequate glandular function during cancer treatment $[8,23]$. The involvement of these glands facilitates aggression to the soft tissues, affecting the integrity of the oral mucosa, which is devoid of salivary lubrication protection, providing favorable conditions for the occurrence of secondary infections $[4,5,8]$.
Modifications produced in the salivary glands include actinic and adipose degeneration, in addition to fibrosis, with a marked decrease in salivary flow and increase in the viscosity of saliva. There are significant increases in osmolality and viscosity, andconcentrations of lactoferrin, protein, sodium and chloride $[22,24]$.

Changes in saliva composition due to antineoplastic therapy, both quantitative and qualitative, cause reduced salivary flow, decreased salivary $\mathrm{pH}$, reduced buffer capacity, and changes in amylases and IgA activity, resulting in acidification of the medium. Also alterations in various electrolytes such as calcium, potassium, sodium and phosphate occur, creating favorable conditions for the establishment and proliferation of oral microorganisms, such as mutans streptococci, Candida albicans and Lactobacillus spp. Accordingly, this makes patients more susceptible to a series of pathologies such as dysgeusia, atrophy oflingual papillae, angular cheilitis, halitosis, candidiasis, periodontal diseases and development of caries $[4,5,22-24]$.

The increase in the incidence of dental caries, frequently observed in xerostomic patients, is due to the excessive accumulation of dental plaque. In addition, patients with xerostomia usually eat sweets and acidic foods to alleviate their symptoms, which tends to increase the risk of dental caries [23] .

Xerostomic patients also have difficulties with the use of prostheses. The lack of saliva decreases the retention of the prosthesis, allowingit to shift, causing discomfort to the patient [25].

The oral discomfort due to the dry mouth sensation becomes even greater, as it negatively affects speaking, swallowing and chewing, compromising the patient's QoL and even their adherence to antineoplastic treatment $[5,8]$.

\section{Prevention and treatment}

The importance of oral health care is indisputable in the pre-, trans- and post-treatment periods cancer patients. It would be ideal for cancer patients to have a dental evaluation before antineoplastic treatment, aimed at prevent the main oral complications due to RT and CT [26].

The planning of dental treatment should prioritize oral hygiene guidance for a better control of possible oral complications and control of stomatognathic functions. It should be performed with the objective of eliminating 
sources of trauma, such as orthodontic appliances, poorly fitting prostheses, or fractured teeth orrestorations, which may damage already fragile mucosa, extraction of septic teeth and treatment of periodontal disease, thereby preventingopportunisticinfection [26].

The treatment of xerostomia is mainly palliative. It can be carried out through the use of masticatory, gustatory or electronicstimulants, saliva substitutes or systemic agents. Also, alternative methods such as acupuncture are cited as a form of xerostomia treatment. Currently, methods that protect the salivary glands against radiation, such as surgical transfer of the submandibular gland, intensity modulated radiotherapy (IMRT), stem cell therapy, and other methods are being developed to improve the QoL of these patients [27]. The main objective of treatment should be the relief of symptoms associated with xerostomia as well as its complications [28].

\section{Prevention: intensity modulated radiotherapy}

IMRT is a modern technique capable of reducing the effects of radiation on normal tissues. Compared with conventional RT, IMRT provides the delivery ofa specific dose of radiation to the tumor, sparing healthy tissues [27]. It usehigh technology software that optimizes the treatment, where higherdoses are directed at tumor target, while decreasing the doses that are received by adjacent healthy tissues [18].

In the salivary glands, IMRT can minimize the severity of xerostomia and its side effects, since the salivary glands that are spared from radiation, receiving lower doses, tend to maintain the capacity to regenerate over time after treatment, contrary to treatments with conventional radiation $[4,29]$.

Despite the high technology employed, IMRT cannot be used in all cases. With tumors that originate from the midline or cross the midline and in cases of lymph node metastasis, it is not possible to use this technique. In addition, the cost involved in the use and maintenance of this type of equipment is unfavorable to its applicability, especially in non-private services [18].

\section{Intensity modulated proton therapy}

Intensity modulated proton therapy (IMPT) is a similar method as IMRT, where it is used to reduce the dose of radiation to normal tissues, significantly mitigating the side effects of radiation, including xerostomia [27]. It presents intrinsic physical properties that provide the capacity to reduce the total dose delivered to the patients, maintaining a highly conformal target coverage, in turn reducing the toxicity in comparison with current RT external beam photons [30].

Dosimetric studies have demonstrated that the IMPT allows dose reduction for several normal tissue structures, including the submandibular and parotid glands, oral cavity, spinal cord and brain stem [30].

IMPT has been shown to be an excellent technique to prevent xerostomia, mainly by sparing the salivary glands from the effects of radiation. A study using risk models for the development of xerostomia demonstrated a $70 \%$ decrease in side effects [27].

When compared to the IMRT, IMPT achieves similar cure rates [30]. In a study by Ramaekers et al. [30] who compared the two techniques, it was shown that the estimated occurrence of xerostomia and dysphagia at 12 months was lower for patients who underwent IMPT. IMPT was also more effective in all patients, but it is the more costly strategy.

\section{Transfer of salivary glands}

Surgical transfer of salivary glands can be a preventative method to prevent or minimize dry mouth sensation. It is a management strategy where, in the treatment, all salivary glands are included in the radiation fields [31,32].

Surgical transfer of the submandibular gland can be made into the submental space if it is outside the radiation area. This strategy preserves submandibular gland function, and as a positive result, radiation-induced xerostomia is reduced without altering the oncological aim $[29,33]$.

Although it is an excellent technique to prevent xerostomia, surgicalmanipulation of the submandibular gland has the peculiarity of being an invasive procedure. Consideration should be given to the time required for the intervention, adequate infrastructure and specialized professional, and to fact that this procedure does not help patients undergoing $C T$, since this modality exerts a systemic effect, which tends to reduce the number of those benefitting from this measure [4]. 


\section{Therapy with progenitor cells and stem cells}

Recent investigations indicate that transplantation of salivary gland progenitor cells is able to restore homeostasis of gland tissues, reverse hyposalivation, and control xerostomia. These progenitor cells, necessary for the maintenance of the tissues, must be collected before the antineoplastic treatment and are then transplanted to the affected salivary glands after the treatment $[27,34]$.

Since 2004, several studies have been carried out in which stem cellsof the submandibular and parotid salivary glands have been transplanted into animal models after RT35. A newly recognized cell population, called c-kit+, appears to have the ability to restoreorgan function and morphology after radiation of the salivary glands of rodents undergoing antineoplastic treatments. Curiously, these c-kit+ cells are also found in human salivary glands and have the same regenerative potential; however, indepth studies on this potential are still need $[35,36]$.

\section{Transfer of genes}

Gene therapy may be defined as the insertion of a functional gene into certain cells, to correct a cellular dysfunction or to induce a new cellular function. It is currently being used for the treatment of a wide range of human diseases such ascancers, cardiovascular diseases, infectious diseases (including HIV/AIDS), neurological diseases, ophthalmological diseases and inflammatory diseases, among others. Gene therapy has also been studied in the maxillofacial region for the treatment of oral cancer, salivary hypofunction, xerostomia and orofacial pain and for tissue regeneration $[27,37]$.

One of the most important and promising applications of gene therapy in dentistry is targeting the salivary glands. Two major areas of application can be distinguished: prevention and reversal of salivary hypofunction and xerostomia and production in the salivary glands of therapeutic proteins for local or systemic action [27].

Gene therapy is considered an option for salivary hypofunction induced in cancer patients who are treated and who suffer damage to the salivary glands $[27,37]$.

Transfer of genes into cells can be performed using viral and non-viral vectors. Currently, viral vectors are the most used, since they lead to a very efficient gene transfer and produce high levels of transgenic protein, but they are also considered problematic because they present a risk of mutagenesis and can trigger innate, cellular and humoral immune responses [27,37].

DNA transmission poses less security risks but is inefficient in cell transduction; still there are hardly any non-viral vectors for the salivary glands [27].

Although most studies have been done in animal models such as rodents, there are some studies with humans. Clinical investigations have shown that gene transfer is safe and effective and that it is an alternative to minimizing the effects of RTand improving the QoL of patients. However, no oral application of gene therapy is ready for routine clinical use in humans, despite its proven success in animal studies and recent evidence of utility in human clinical trials [36].

\section{Amifostine}

Amifostine is a drug known for its potent cytoprotective effect. It is used to reduce the undesirable effects of certain $C T$ agents and RT, by decreasing the production of FR and consequent imbalance of oxidative stress $[38,39]$.

After administration, amifostine is transformed into an active metabolite by alkaline phosphatase, which penetrates the cell nucleus and scavenges oxidative FR, preventing chromosome damage $[4,28,39]$. This active metabolite is taken up by healthy cells where it provides protection against the harmful effects of RT and CT. It is preferentially accumulated in certain tissues, including salivary glands, making them less sensitive to damage $[28,29]$. It exerts its protective action inactivating FR and inducing cellular hypoxia, thus preventing the fixation effect of molecular lesions caused by oxygen (O2). Its accumulation in healthy cells is 100 times higher than in neoplastic cells, due to the action of cellular alkaline phosphatases, vascularization and higher $\mathrm{pH}$ in normal tissue $[4,39]$. Thus, it is believed that tumor cells are more exposed to the deleterious effects of treatment and thathealthy cells are more protected [4].

To reduce the severity of xerostomia, amifostine can be used during and after CT and RT. It has the capacity to provide direct radioprotection to the salivary glands when large part of them is included in the radiation field $[28,29]$. It is given intravenously with a daily dose of $200 \mathrm{mg} / \mathrm{m}^{2}$ 
before each session $[4,36,39]$. Although the actual range of benefits depends on the particular aspects of each patient and the treatment established, such as dose, fractionation and glandular involvement, amifostine has been shown to reduce the occurrence of xerostomia in irradiated patients [4].

A limitation of this type of intervention is that the intravenous administration of amifostine is accompanied by many side effects [36]. Its use is debatedin view of the severe adverse effects that it produces such as nausea, vomiting and hypotension, and some studies still question the potential of protection to the tumor cells [38]. Thus, the controversy continues as to whether amifostine is safe for use in cancer patients [36].

\section{Tempol}

Tempol is a stable nitroxide that provides selective radioprotection against salivary gland damage [36]. It is an emerging radioprotective drug, administered systemically (intravenously and subcutaneously) or topically (mouthwash and gel). It has several mechanisms of action, including imitation of superoxide dismutase activity, oxidation of transition metals and FR elimination, being considered a potent antioxidant capable of limiting oxidative stress [40].

Its radioprotective potential was observed when administered 5-10 min before radiation [40]. Studies in rats indicate that salivary gland dysfunction can be considerably reduced by the administration of this agent. In addition, tempol tends to provide protection only for salivary glands, without protecting tumor tissue [28]. These studies further support the development of clinical trials on the use of tempol in humans to prevent xerostomia $[36,40]$.

\section{Growth factors}

Some preventive treatments of xerostomia include systemic administration of growth factors such as insulinlike growth factor-1 (IGF-1) or keratinocyte growth factor (KGF). In studies, both factors have been evaluated in rats and shown to protect the salivary glands, preserving their functions through two possible mechanisms: increasing the survival and proliferation of salivary acinar cells and stem cells and suppressing the apoptosis of these cells [40].

The administration of IGF-1 has been shown to reduce apoptosis in thesalivary glands induced by antineoplastic treatment and to preserve their function, suggesting a causal relationship between apoptosis and salivary dysfunction [36].

The use of keratinocyte growth factor (KGF), administered subcutaneously, before or shortly after CT or RT, has been shown to reduce hyposalivation. Its postRT administration caused an accelerated growth of the group ofprogenitor/stem cells that survived the irradiation treatment [36].

The Food and Drug Administration (FDA) has not approved IGF-1injectionin humans for several important applications, such as diabetes and amyotrophic lateral sclerosis, so approval for xerostomia treatmentseems unlikely. In addition, further studies are needed on the use of growth factors as preventive agents for xerostomia [40].

\section{Treatment strategies}

\section{Botulinum toxin}

The intraglandular application of botulinum toxin has been investigated, and results showed this to be a promising pharmacological approach for xerostomia induced by antineoplastic treatments. The mechanism of action of this treatment is not yet clear; apparently, botulinum toxin reduces the secretory activity of the gland by reducing nerve stimulation, decreasing the sensitivity of acinar tissues to CT and RT $[4,40]$. Transient denervation of the salivary glands occurs, which causes reduced salivary secretion, structural and functional alterations, atrophy and reduced amounts of secretory granules in acinar cells [32].

Studies in animal models demonstrate that if botulinum toxin is administered before RT, it can lead to temporary glandular involution, which results in decreased saliva production during $\mathrm{RT}$; this prevents the concentration of radiation where there aresaliva inorganic solutes, which can significantly reduce radiation sensitivity $[32,40]$. In addition, botulinum toxin has been shown to increase tumor response to RT, suggesting that this treatment would not pose the risk of tumor protection [40].

Because botulinum toxin is already an FDA-approved drug for many applications, clinicians are likely to be inclined to prescribe cytoprotective treatment, but there are not yet any experimentally established protocols for its clinical use $[4,40]$. 


\section{Acupuncture}

Acupuncture originated in China more than three thousand years ago. It consists of the insertion of needles into specific points of the body, called acupoints, which are closely related to nerves, blood vessels, tendons, periosteums and joint capsules. Thus, direct stimulation of the central nervous system is possible. Acupuncture aims to regulate the physical, mental, mental and spiritual functions, attaining energy balance.

The stimulation of acupoints has the capacity to increase the release of CGRP (calcitonin generelatedpeptide) from the nerve endings of the autonomic and peripheral nervous system, thus raising the salivary flow [8].

A study by Ghazzaoui et al. [7] suggests that acupuncture influences the autonomic nervous system, which stimulates the salivary glands, to release increased amounts of neuropeptides which, in turn, can cause blood vessel dilation and increased salivary secretion. It was possible to observe that the patients submitted to acupuncture had an increase in saliva production and consequently an increase in blood flow [8].

Acupuncture is applied in an integral and dynamic way and can be used alone or in an integrated way with other therapeutic resources. Acupuncture treatment should be maintained for at least six months and its effects last for up to 3 years $[27,29]$.

It is proven that acupuncture provides benefits in the treatment of individuals with xerostomia [8]. The stimulation of salivary secretion by acupuncture showed promising results in patients who are undergoing or will undergo head and neck RT [27]. Among the benefits of acupuncture in patients with xerostomia are increased salivary flow and improvement in eating, speech and sleep quality, providing better QoL to these patients $[41,42]$.

\section{Low-power laser therapy}

The late effects of RT and CT are increasingly beingaddressed, considering the increase in the life expectancy of cancer patients [43]. One possible approach to effective treatment for hyposalivation and xerostomia is low-power laser therapy [44].

Low-power laser light has demonstrated efficacy in the treatment of innumerable complications or diseases, as it allows biomodulation of cellular metabolismand exerts analgesia and anti-inflammatory effects, without mutagenic and photothermal effects [6]. Its effects based on modulation of metabolic metals and biochemical and photophysical processes, transform the laser light into useful energy for the cells [45].

It is believed to improve local microcirculation, induce glandular cell proliferation, and increase cellular respiration, ATP production, protein synthesis and intracellular calcium levels [43]. Because it is a non-invasive technique, affordable and easy to apply, it could be available in the clinical routine of oncology services [6].

However, in the literature, there is still controversyover low-power laser. While some studies suggest that laser would be able to increase residual saliva production or decrease dry mouth sensation, other authors report only obtaining non-significant improvements [4].

However, considering that this intervention is effective in attenuating salivary hypofunction after antineoplastic treatments and can maintain the salivary flow within the normal range, laser therapy is highly desired by patients and may offer a lower impact of CT and RT on patients' QoL [6].

\section{Sialogogues/saliva substitutes}

Sialogoguesare any form of salivary stimulant, promoting the function of the salivary glands, consequently increasing their saliva flow [28]. Stimulants and salivary replacements are used as alternatives to control the symptoms of xerostomia already established [9].

The effect of sialogogues can be achieved by gustatory or masticatory stimulation or by the use of medication [28].

The gustatory form is by the ingestion of citrus fruits such as apple and pear or by the use of simple liquids such as bicarbonate solutions, water with lemon drops, chamomile tea, saline or water containing hydrogen peroxide [46]. Saliva stimulation can also be achieved by sucking vitamin C tablets. However, the use of water with lemon and vitamin $C$ tablet has an erosive action that can cause discomfort in the oral and gastric mucosa [9].

In masticatory stimulation, chewing gums without sugar are recommended, which usually do not have adverse effects [46]. Chewing gum increases salivary flow by the 
masticatory and gustatory stimulus. The use of chewing gum increases the buffering capacity of saliva by increasing salivary flow; this increase in salivary flow, in the absence of significant production of acid, as occurs in gums sweetened with sorbitol and xylitol, increases the $\mathrm{pH}$ of saliva and biofilm, maintaining $\mathrm{pH}$ levels [47]. Edentulous patients, individuals with poorly fitting prostheses, individuals with temporomandibular dysfunction (TMD), and those with intolerance to gum components are contraindicated for the use of chewing gums. Chewing gum promotes immediate and long-lasting increase in salivary flow [46].

Another non-pharmacological intervention is the massage of the parotid gland, used to reduce the damage to the salivary glands, reducing the accumulation of radioactive iodine [48].

A new alternative for the control of xerostomia is the use of thyme honey, which is a propolis gel product. It is believed that the presence of honey in the oral cavity has a sialagogue effect, stimulating the salivary glands to produce more saliva, due to the high sugar concentration in honey [49].

There is a long list of pharmacological sialogogues, but only two drugs are approved by the FDA for the treatment of xerostomia: pilocarpine and cevimeline $[38,40]$

Pilocarpine is a natural alkaloid with a wide range of biological targets, acting as a parasympathetic mimic, where it is a non-selective agonist of muscarinic receptors, mimicking saliva-inducing nerve signals, stimulating glandular function, so it does not block the effect of CT and RT $[4,38-40]$. The beneficial effect of this drug depends on the dose received by the glands. It is available in $5-\mathrm{mg}$ tablets, is given orally three to four times daily, for a dose of 5-10 mg every $8 \mathrm{~h}$ (maximum daily dose of $30 \mathrm{mg}$ ). The incidence of adverse effects depends on the dose, which are derived from the cholinergic effect: sweating, nausea, epiphora, abdominal pain, facial redness, increased urinary frequency, diarrhea, bronchospasm, hypotension and bradycardia [38,39].

Its effects on irradiated patients remain under discussion. In a study by Gaetti Jardim Júnior et al. [4], it was shown that dry mouth sensation can be significantly reduced, but objective evidence suggests that the effects of pilocarpine on salivation may only be limited. Sasportas et al. [39] showed that although the increase in salivary flow has been shown, there may be no difference in the subjective perception of xerostomia. In addition, pilocarpine seems to be more effective if given in pretreatment with $\mathrm{RT}$, and in post-radiation, it could then have a preventive effect.

Sousa et al. [9] reported that pilocarpine applied or administered before RT has a protective and preventive action in the salivary glands, reducing post-radiation xerostomia and optimizing therapy. When pilocarpine is administered only after or during RT, it does not produce impressive results, with a low percentage of success with regard to increased salivary flow, but the symptoms of xerostomia are minimized.

The stimulatory effectsof these sialogogues are of short duration and disappear once the patient discontinues treatment, so these drugs need to be taken for patient's entire life [40-48]. Due to their cholinergic effect, these drugs have contraindications such as asthma, chronic obstructive pulmonary disease, heart failure, epilepsy, hyperthyroidism, glaucoma, gastric ulcer and Parkinson's disease [38].

When salivary function is zero, it cannot be stimulated. In these cases, saliva substitutes should be used to moisten the mouth [9]. The use of natural saliva substitutes in patients who do not respond to drugs, gustatory or masticatory stimulation aims to minimize the effects of xerostomia on the stomatognathic apparatus $[4,50] 0$. Saliva substitutes have been shown to be useful in alleviating xerostomia [38]. They have a neutral $\mathrm{pH}$, electrolytes at asimilar concentration as natural saliva, similar physical properties as glycoproteins and antibacterial activity $[38,49]$. They are marketed in the form of moisturizing gels, mouthwashes or sprays [49].

These substitutes are composed of carboxymethylcellulose and a mucin base [9]. They should be used before meals and before bed, according to the need of the patient, and their use can be extended, repeating several times a day [46]. Mucin-based products are more effective and better tolerated and act longer; they are particularly beneficial in irradiated patients [38]. However, it is worth trying different types of saliva substitutes in a specific patient to select the most effective [36]. The major disadvantage of saliva substitutes is the shorter duration of relief they provide [49]. There are many products on the market such as Bucalsone ${ }^{\circledR}$, Bucohidrat ${ }^{\circledR}$, Biotene ${ }^{\circledR}$, Moi-STIR ${ }^{\circledR}$, Kote $^{\circledR}$ Mouth, Oral Balance ${ }^{\circledR}$, Salivart ${ }^{\circledR}$, Xero-Lube, Xerostom ${ }^{\circledR}$, Kin Hidrat, On Care, Xerolacer, Salivan, Halicare andBioextra. 
These have different compositions and forms, which should be considered in their indication [38].

Sialogogues and saliva substitutes are alternatives for the treatment of xerostomia. It is important to emphasize that for normal production of saliva, the patient needs to be hydrated, and therefore, the increase in water intake is essential. The prescription of this type of treatment should be guided according to the need and acceptability of the patient [46].

\section{FINAL CONSIDERATIONS}

In this review we were able to address information about xerostomia or the dry mouth sensation, which affects both treatments and the quality of life of cancer patients.

The search for protective agents against the harmful effects of cancer treatments continues to be a challenge for oralsurgeons. The forms of prevention currently developed have been shown to be effective, but they present limitations such as costs and side effects, so further in-depth research is needed in animal models and in clinical trials.

Treatments show positive results in increased saliva production and decreased dry mouth sensation. These treatments should be performed for a long period of time, some can be for the entire life of the patient.

We conclude that xerostomia treatment is multidisciplinary, involving various health professionals, and that there are currently several preventive and treatment methods that minimize the damage caused by xerostomia.

\section{Collaborators}

T BARBIERI, KC COSTA and LFC GUERRA conceived and planned this paper. T BARBIERI and KC COSTA carried out the searches. LFC GUERRA contributed to the interpretation of the results. T BARBIERI, KC COSTA and LFC GUERRA took the lead in writing the manuscript. All authors provided critical feedback and helped shape the research, analysis and manuscript.

\section{REFERENCES}

1. Instituto Nacional de Câncer [Internet]. Rio de Janeiro; 19962017 [citado 2017 mai. 3]. Disponível em: <http://www.inca. gov.br>.

2. Tartari RF, Busnello FM, Nunes CHA. Perfil nutricional de pacientes em tratamento quimioterápico em um ambulatório especializado em quimioterapia. Rev Bras Cancerologia. 2010;56(1):43-50.

3. Caccelli EMN, Pereira MLM, Rapoport A. Avaliação da mucosite e xerostomia como complicações do tratamento de radioterapia no câncer de boca e orofaringe. Rev Bras Cir Cabeça Pescoço. 2009;38(2):80-83.

4. Gaetti Jardim Júnior E, Souza FRN, Dias N, Jesus KG, Schweitzer CM. Xerostomia em pacientes irradiados. Rev Visão Universitária. 2015;3(1):31-54.

5. Gaetti Jardim Júnior E, Souza FRN, Vieira APM, Ranieri RV, Schweitzer CM. Xerostomia e outros efeitos colaterais da radioterapia de cabeça e pescoço em uma população sem tratamento odontológico prévio. Rev Visão Universitária. 2015;3(1):90-108.

6. Gonnelli FAS, Palma LF, Giordani AJ, Deboni ALS, Dias RS, Segreto RA, et al. Laser de baixa potência para prevenção de hipofluxo salivar em pacientes portadores de câncer de cabeça e pescoço após radioterapia e quimioterapia. Radiol Bras. 2016;49(2):86-91.

7. Ghazzaoui SF, Romano LTC, Gonnelli FAS, Palma LF. Acupuntura para xerostomia e hipofluxo salivar: revisão de literatura. Rev Bras Odontol. 2016;73(4):340-343. http:// dx.doi.org/10.18363/rbo.v73n4.p.340

8. Goulart JD, Almeida JC, Leardini JMS, Silva JF, Abrahão JMB, Silva JB, et al. Xerostomia e suas causas na Odontologia. Rev Eletr Acervo Saúde. 2016;3:99-103.

9. Sousa NB, Freitas HV, Almeida-Junior LJS, Lopes FF, Cruz MCFN. Abordagem crítica sobre as terapias de estimulação do fluxo salivar (TEFS). Rev Pesq Saúde. 2014;15(1):245-248.

10. Deasy JO, Moiseenko V, Marks L, Chao C, Nam J, Eilsbruch A. Radiotherapy Dose-Volume Effects on Salivary Gland Function. Int J Radiat Oncol Biol Phys. 2010; 76(30):58-63. http://dx.doi.org/10.1016/j.ijrobp.2009.06.090.

11. Chung MK, Kim do H, Ahn YC, Choi JY, Kim EH, Son YI. Randomized trial of Vitamin C/E complex for prevention of radiation-induced xerostomia in patients with head and neck cancer. Otolaryngol Head Neck Surg. 2016;155:423-430. http://dx.doi.org/10.1177/0194599816642418.

12. Acauan MD, Figueiredo MAZ, Cherubini K, Gomes APN, Salum FG. Radiotherapy-induced salivary dysfunction: Structural changes, pathogenetic mechanisms and therapies. Arch Oral Biol. 2015;60(12):1802-1810. http://dx.doi.org/10.1016/j. archoralbio.2015.09.014.

13. Freire AAS, Honorato PSM, Macedo SB, Araújo CS. Manifestações bucais em pacientes submetidos a tratamento quimioterápico no hospital de câncer do acre bucal. J Amazon Health Sci. 2016;2(1):1-21.

14. Jesus LG, Cicchelli M, Martins GB, Pereira MCC, Lima HS, Medrado ARAP. Repercussões orais de drogas antineoplásicas: uma revisão de literatura. Rev Fac Odontol. 2016;21(1):130-135.

15. Araujo TLC, Mesquita LKM, Vitorino RM, Macedo AKMN, Amaral RC, Silva TF. Manifestações bucais em pacientes submetidos a tratamento quimioterápico. Rev Cubana Estomatol. 2015;52(4):16-21.

16. Hespanhol FL, Tinoco BEM, Teixeira HGC, Falabella MEV, Assis NMSP. Manifestações bucais em pacientes submetidos à 
quimioterapia. Ciênc Saúde Coletiva. 2010;15(1):1085-1094 https://doi.org/10.1590/S1413-81232010000700016

17. Mravak-Stipetić M. Xerostomia - diagnosis and treatment Med Sci. 2012;38(1):69-91.

18. Masulo LJ, Muñoz ISS, COSTA DR, Maciel TSM, Nicolau RA. Xerostomia: etiologia, diagnóstico e tratamento: revisão de literatura. XVII Encontro Latino Americano de Iniciação Científica - UNIVAP; 2013.

19. Memtsa PT, Tolia M, Tzitzikas I, Bizakis J, Gombaki KP, Charalambidou $M$, et al. Assessment of xerostomia and its impact on quality of life in head and neck cancer patients undergoing radiation therapy. Molecular And Clinical Oncology. 2017;6:789-793. http://dx.doi.org/10.3892/mco. 2017.1200

20. Plemons JM, Al-Hashimi I, Marek CL, American Dental Association Council on Scientific Affairs. Managing xerostomia and salivary gland hypofunction: executive summary of a report from the American Dental Association Council on Scientific Affairs. J Am Dent Assoc. 2014;145(8):867-873. http:// dx.doi.org/10.14219/jada.2014.44

21. Freitas DA, Caballero AD, Pereira MM, Oliveira SKM, Silva GP, Hernández CIV. Sequelas bucais da radioterapia de cabeça e pescoço. Rev Cefac. 2011;13(6):1103-1108.

22. Tanasiewicz M, Hildebrandt T, Obersztyn I. Xerostomia of various etiologies: a review of the literature. Adv Clin Exp Med. 2016;25(1):199-206. http://dx.doi.org/10.17219/acem/2 9375.

23. Randall K, Stevens J, Yepes JF, Randall M, Kudrimoti M, Feddock $J$, et al. Analysis of factors influencing the development of xerostomia during intensity-modulated radiotherapy. Oral Surg Oral Med Oral Pathol Oral Radiol. 2013;115(6):772-779. http://dx.doi.org/10.1016/j.0000.2013.01.006.

24. Mohsin AHB, Reddy V, Kumar P, Samee S. Aloe vera for dry mouth denture patients - palliative therapy. J Clin Diagn Res. 2017;11(6):20-23. http://dx.doi.org/10.7860/jcdr/2017/25084. 10036.

25. Anderson L, Medeiros FB, Ciamponi AL. Cuidados odontológicos em pacientes oncológicos. Onco. 2014:24-25.

26. Vissink A, Van Luijk P, Langendijk JA, Coppes RP. Current ideas to reduce or salvage radiation damage to salivary glands. Oral Dis. 2014;21(1):1-10. http://dx.doi.org/10.1111/odi.12222

27. Tariq A, Jamshaid $M$, Majeed I. Xerostomia: post radiation management strategies. Int J Pharmac Res Allied Sci. 2015;4(3):35-47.

28. Jensen SB, Pedersen AM, Vissink A, Andersen E, Brown $C G$, Davies $A N$, et al. A systematic review of salivary gland hypofunction and xerostomia induced by cancer therapies: management strategies and economic impact. Support Care Cancer. 2010;18(8):1061-1079. http://dx.doi.org/10.1007/s005 20-010-0827-8

29. Blanchard P, Garden AS, Gunn GB, Rosenthal DI, Morrison $\mathrm{WH}$, Hernandez $\mathrm{M}$, et al. Intensity-modulated proton beam therapy (IMPT) versus intensity-modulated photon therapy (IMRT) for patients with oropharynx cancer: a case matched analysis. Radiot Oncol. 2016; 120(1):48-55. http://dx.doi.org/10. 1016/j.radonc.2016.05.022
30. Ramaekers BLT, Grutters JPC, Pijls-Johannesma M, Lambin P, Joore MA, Langendijk JA. Protons in Head-and-Neck Cancer: Bridging the Gap of Evidence. International J Rad Oncol Biol Physics. 2013;85(5):1282-288. http://dx.doi.org/10.1016/j. ijrobp.2012.11.006

31. Kaluzny J, Wierzbicka M, Nogala H, Milecki P, Kopec T. Radiotherapy induced xerostomia: Mechanisms, diagnostics, prevention and treatment: evidence based up to 2013. Otolaryngol Pol. 2014;68(1):1-14. http://dx.doi.org/10.1016/j. otpol.2013.09.002

32. Sood AJ, Fox NF, O'Connell BP, Lovelace TL, Nguyen SA, Sharma AK, et al. Salivary gland transfer to prevent radiationinduced xerostomia: a systematic review and meta-analysis. Oral Oncol. 2014;50(2):77-83. http://dx.doi.org/10.1016/j. oraloncology.2013.10.010

33. Coppes RP, Stokman MA. Stem cells and the repair of radiationinduced salivary gland damage. Oral Dis. 2011;17(2):143153. http://dx.doi.org/10.1111/j.1601-0825.2010.01723.x

34. Nevens D, Nuyts $S$. The role of stem cells in the prevention and treatment of radiation-induced xerostomia in patients with head and neck cancer. Cancer Med. 2016; 5(6):1147-1153. http://dx.doi.org/10.1002/cam4.609

35. Vissink A, Mitchell JB, Baum BJ, Limesand KH, Jensen SB, Fox $P C$, et al. Clinical management of salivary gland hypofunction and xerostomia in head-and-neck cancer patients: successes and barriers. Int J Radiat Oncol Biol Phys. 2010;78(4):983991. http://dx.doi.org/10.1016/j.ijrobp.2010.06.052

36. Alevizos I, Zheng C, Cotrim AP, Liu S, McCullagh L, Billings $\mathrm{ME}$, et al. Late responses to adenoviral-mediated transfer of the aquaporin-1 gene for radiation-induced salivary hypofunction. Gene Ther. 2017; 24(3): 176-186. http://dx.doi. org/10.1038/gt.2016.87

37. Ulloa JP, Fredes F. Manejo actual de la xerostomia. Rev Otorrinolaringol Cir Cabeza Cuello. 2016;76:243-248. http:// dx.doi.org/10.4067/s0718-48162016000200017

38. Vives-Soler A, López-López J, Jané-Salas E. Xerostomía y radioterapia de cabeza y cuello: actualización. Rev Colomb Cancerol. 2017;21(1):26-32. http://dx.doi.org/10.1016/j.rccan. 2016.06.001

39. Sasportas LS, Hosford AT, Sodini MA, Waters DJ, Zambricki EA, Barral JK, et al. Cost-effectiveness landscape analysis of treatments addressing xerostomia in patients receiving head and neck radiation therapy. Oral Surg Oral Med Oral Pathol Oral Radiol. 2013;116(1):37-51. http://dx.doi.org/10.1016/j. oooo.2013.02.017

40. Pereira MSS, Silva BO, Santos FR. Acupuntura: terapia alternativa, integrativa e complementar na Odontologia. Rev CROMG. 2015;16(1):19-26.

41. Saito LT, Silvério-Lopes S, Pontes SRB, Suliano LC. Acupuntura sistêmica no tratamento de xerostomia decorrente do uso de anti-hipertensivos: estudo de casos. Rev Bras Terap Saúde. 2012;3(1):9-13. http://dx.doi.org/10.7436/rbts-2012.03.01.02

42. Palma LF, Gonnelli FAS, Marcucci M, Dias RS, Giordani AJ, Segreto RA, et al. Impact of low-level laser therapy on hyposalivation, salivary $\mathrm{pH}$, and quality of life in head and neck cancer patients post-radiotherapy. Lasers Med Sci. 
2017;32(4):827-832. http://dx.doi.org/10.1007/s10103-0172180-3

43. Dabić DT, Jurišić S, Boras VV, Gabrić D, Bago I, Vrdoljak DV. The effectiveness of low-level laser therapy in patients with drug-induced hyposalivation: a pilot study. Photomedicine Laser Surg. 2016; 34(9): 389-393. http://dx.doi.org/10.1089/ pho.2016.4109

44. Saleh J, Figueiredo MAZ, Cherubini K, Braga-Filho A, Salum FG. Effect of low-level laser therapy on radiotherapy-induced hyposalivation and xerostomia: a pilot study. Photomedicine Laser Surg. 2014;32(10):546-552. http://dx.doi.org/10.1089/ pho.2014.3741

45. Silva IJO, Almeida ARP, Falcão NC, Freitas Junior AC, Bento PM, Queiroz JRC. Hipossalivação: etiologia, diagnóstico e tratamento. Rev Bahiana Odontol. 2016;7(2):140-146. http:// dx.doi.org/10.17267/2238-2720revbahianaodonto.v7i2.856

46. Montanuci LMGM, Volpato LER, França DCC, Aguiar SMHCA, Machado MAAM. Efeito de diferentes gomas de mascar sobre o pH salivar de crianças. Pesq Bras Odontopeda
Clín Integr. 2013;13(1):23-29. http://dx.doi.org/10.4034/ pboci.2013.131.04

47. Charalambous A. Seeking optimal management for radioactive iodine therapy-induced adverse effects. Asiapacific J Oncol Nursing. 2017;4(4):319-322. http://dx.doi. org/10.4103/apjon.apjon_23_17

48. Charalambous A, Lambrinou E, Katodritis N, Vomvas $D$, Raftopoulos V, Georgiou M, et al. The effectiveness of thyme honey for the management of treatment-induced xerostomia in head and neck cancer patients: a feasibility randomized control trial. Eur J Oncol Nurs. 2017;27:1-8. http://dx.doi.org/10.1016/j.ejon.2017.01.001

49. Agbo-Godeau S, Guedj A, Marès S, Goudot P. Sécheresse buccale (xérostomie). La Presse Médicale. 2017;46(3):296302. http://dx.doi.org/10.1016/j.lpm.2017.02.004

Received on: 30/10/2019

Final version resubmitted on: 17/3/2020

Approved on: 14/4/2020 